\title{
Simulation of Bilirubin Detoxification in the Newborn Using an Extracorporeal Bilirubin Oxidase Reactor
}

\author{
CLAUDY J.-P. MULLON, CHRISTINE M. TOSONE, AND ROBERT LANGER \\ Department of Chemical Engineering, MIT, Cambridge, Massachusetts 02139 [C.J-P.M., C.M.T., R.L.]; \\ Harvard-MIT Division of Health Science and Technology, Whitaker College of Health Sciences, Cambridge, \\ Massachusetts, 02139 and Department of Surgery, Boston Children's Hospital, Boston, \\ Massachusetts 02115 [R.L.]
}

\begin{abstract}
Jaundice, which is characterized by an excessive accumulation of bilirubin in the blood and tissues, occurs in $13 \%$ of newborns. The common treatments for neonatal jaundice are phototherapy and blood exchange transfusion. A novel approach using an extracorporeal blood filter containing immobilized bilirubin oxidase was recently proposed to detoxify jaundiced blood, and a prototype device markedly reduced serum bilirubin in genetically jaundiced Gunn rats. The primary toxicologic effect in that study was a $20 \%$ reduction in red blood cell count. Using a compartmental model for bilirubin metabolism, a mathematical simulation of the extracorporeal treatment's ability to reduce serum bilirubin levels in jaundiced infants is presented. Using a $10-\mathrm{mL}$ reactor volume containing immobilized bilirubin oxidase, the simulation predicts a 32 to $65 \%$ decrease in plasma bilirubin concentration over a 4-h treatment for a $2 \mathrm{~kg}$ preterm hyperbilirubinemic newborn. In addition, a new approach to altering support material has essentially eliminated red blood cell lysis in vivo using Gunn rats and in vitro using adult blood. (Pediatr Res 26: 452-457, 1989)
\end{abstract}

Bilirubin originates in the body with the catabolism of the cyclic tetrapyrroles, the major pigment in bilirubin production being $\mathrm{Hb}(1)$. All human newborns accumulate bilirubin to levels greater than those in adults, and $20 \%$ accumulate enough to stain their skin, resulting in jaundice (2). Clinically elevated bilirubin levels have been associated with mental retardation, cerebral palsy, seizures, deafness, or death (2).

The two most common treatments for neonatal jaundice are phototherapy and exchange transfusion. In phototherapy, bilirubin is converted to more readily excreted photoisomers by exposing the infant to blue light. Phototherapy has been used extensively for plasma bilirubin concentrations up to $15 \mathrm{mg} / \mathrm{dL}$, but it suffers from the inherent limitation that the total plasma bilirubin concentration can be lowered by only 15 to $20 \%$ within $48 \mathrm{~h}(3,4)$. In addition, the possible long-term dangers of exposing the newborn to blue light have not been fully evaluated. DNA as well as several essential amino acids and vitamins have been shown to be light sensitive $(5,6)$.

For severe cases of jaundice (plasma bilirubin $>15 \mathrm{mg} / \mathrm{dL}$ ), it may be necessary for the infant to undergo exchange transfusion.

November 21, 1988; accepted June 27, 1989.

Correspondence Professor R. Langer, Department of Chemical Engineering, E25-342, Massachusetts Institute of Technology, Cambridge, MA 02139.

Supported by Grant GM25810 from the National Institutes of Health.
This involves the replacement of the infant's blood with bilirubin-free adult blood. This procedure presents several risks, including blood damage, fluid shifts, risk of transmission of infectious diseases, and possibly death (2).

Although these treatments have reduced the occurrence of bilirubin toxicity, the associated risks remain a serious problem. Lavin et al. (7) reported the use of a highly specific enzyme to remove bilirubin from the bloodstream. With this method, a small reactor containing a bilirubin detoxifying enzyme is placed in an extracorporeal circuit and the bilirubin detoxified blood is returned to the patient. A prototype device markedly reduced serum bilirubin concentrations in vitro using human umbilicalcord blood to which bilirubin was added, and in vivo using genetically jaundiced Gunn rats. The primary toxicologic effect observed in the previous studies was a $20 \%$ reduction in red blood cell count (7).

This report evaluates the efficacy of the extracorporeal treatment by providing a mathematical simulation of the reduction in plasma bilirubin in jaundiced newborns. Also, a new approach is presented that essentially eliminates red blood cell lysis in vitro with adult blood and in vivo with Gunn rats by altering the support material in the reactor.

\section{MATERIALS AND METHODS}

Reagents. All reagents were analytical grade. Lyophilized bilirubin oxidase (EC.1.3.3.5) obtained from Myrothecium verrucaria MT-1 (Amano International Enzyme Co. Troy, VA.) had a specific activity of $2.27 \mathrm{U} / \mathrm{mg}$. One unit of bilirubin oxidase is defined as the enzyme quantity which can oxidize $1 \mu \mathrm{mol}$ of bilirubin per min in a phosphate buffer $(0.05 \mathrm{~mol} / \mathrm{L}, \mathrm{pH} 7.4)$ containing $20 \mu \mathrm{mol} / \mathrm{L}$ bilirubin, $30 \mu \mathrm{mol} / \mathrm{L}$ serum albumin, and $20 \mathrm{mmol} / \mathrm{L}$ sodium-cholate. Bilirubin was purchased from Porphyrin Products (Logan, UT) and was used without further purification. Tresyl-Chloride (2,2,2-trifluoroethanesulfonyl chloride) was from Fluka AG (Ronkonoma, NY). Nonactivated Biogel A 1.5 (8\% agarose) beads were from Bio-Rad Laboratories (Rockaway, NY). Sephadex G-25 was from Pharmacia Fine Chemicals (Uppsala, Sweden). Heparin (sodium injection, 10,000 USP U/mL) was from Elkins-Sinn, Inc. (Cherry Hill, NJ).

Assays. The enzyme protein concentration was determined by the method of Lowry et al. (8) (Sigma research kits and reagent no. P5656, Sigma Chemical Co., St Louis, MO) using BSA (Sigma) as a standard. Serum albumin concentrations were measured by the method of Doumas et al. (9) (Sigma diagnostic kit and reagent no. 631; Sigma) using BSA or rat serum albumin (Sigma) as standard. Total plasma bilirubin concentrations were 
determined using the method of Jendrassik and Grof (10) (Sigma diagnostic kit and reagent no. 605; Sigma).

Preparation of activated agarose beads. The agarose beads were screened using sieves of different mesh sizes (USA Standard Sieve Series, Newark Wire Cloth Co., Newark, NJ) and beads ranging from 180 to $250 \mu \mathrm{m}$ in diameter were used. The volume of swollen beads was measured by centrifugation in a graduated tube at $1000 \times g$ for a period of $5 \mathrm{~min}$.

The beads were activated by a sulfonyl chloride method using tresyl-chloride under anhydrous conditions as described by Nilsson and Mosbach (11). Using elemental sulfur analysis (12), the activation yield was $325 \mu$ moles of tresylate groups per dry g of agarose.

Bilirubin oxidase immobilization and activity. Lyophilized bilirubin oxidase powder contained approximately $50 \% \mathrm{wt} / \mathrm{wt}$ protein. To remove the salts present in the crystalline enzyme, the powder was dissolved in sodium bicarbonate buffer $(0.02$ $\mathrm{mol} / \mathrm{L}, \mathrm{pH} \mathrm{8.3)}$ and the solution passed over a 25-mL Sephadex G-25 column preequilibrated with the buffer. The enzyme solution examined by SDS-PAGE, as described by Yang et al. (13) showed a single protein band indicating high enzyme purity. Immobilization of bilirubin oxidase onto tresyl-chloride activated agarose beads was performed as described by Comfort et al. (12). Briefly, $1 \mathrm{~mL}$ of enzyme solution at a concentration of $3 \mathrm{mg} / \mathrm{mL}$ was incubated at $22^{\circ} \mathrm{C}$ for $4 \mathrm{~h}$ in the presence of $1 \mathrm{~mL}$ of active beads. To desorb noncovalently bound enzyme molecules, the support was washed with several volumes of a PBS $(0.5 \mathrm{~mol} / \mathrm{L} \mathrm{NaCl}, 0.07 \mathrm{~mol} / \mathrm{L}$ phosphate, $\mathrm{pH} 7.0)$ as described by Mullon et al. (14). The amount of enzyme immobilized determined from the difference between the initial total protein and the amount recovered in the phosphate-saline wash was 1.7 $\mathrm{mg} / \mathrm{mL}$ of beads. The enzymatic activity of the beads was determined at $37^{\circ} \mathrm{C}$ in bilirubin enriched plasma prepared as follows.

Plasma from freshly drawn adult blood heparinized at $10 \mathrm{U} /$ $\mathrm{mL}$ was used. The albumin concentration measured by the method of Doumas et al. (9) was $620 \mu \mathrm{mol} / \mathrm{L}$. A bilirubin solution was prepared by dissolving $5.0 \mathrm{mg}$ of the pigment in a few drops of $0.1 \mathrm{~N} \mathrm{NaOH}$. The solution was protected from the light by aluminum foil and used within 15 min after preparation. The bilirubin enriched plasma solution was then prepared by adding the bilirubin solution to $19.5 \mathrm{~mL}$ of plasma. The $\mathrm{pH}$ of the enriched plasma was adjusted to 7.4 by adding a few drops of $0.02 \mathrm{~N} \mathrm{HCl}$. The enriched plasma contained $420 \mu \mathrm{mol} / \mathrm{L}$ bilirubin and a bilirubin serum albumin molar ratio of 0.69 .

The initial enzymatic activity of the beads was measured spectrophotometrically at $460 \mathrm{~nm}$ by following the disappearance of bilirubin in the bilirubin plasma mixture as described by Mullon et al. (15). Typically, the catalytic activity was $25 \mathrm{nmol} /$ $\mathrm{min} / \mathrm{mL}$ of beads.

Reactor. The reactor was made of agarose beads packed in a $1.5-\mathrm{cm}$ diameter, $10-\mathrm{cm}$ ht column (Biorad Econo-Column, Biorad Laboratories, Richman, CA). The column was maintained at $37^{\circ} \mathrm{C}$ using a $10-\mathrm{cm}$ ht Water-Crest jacket (Thomas Scientific, Swedesboro, NJ) filled with flowing water. Blood was passed through the column using a peristaltic pump (LKB microperpex peristaltic pump, LKB, Sweden) and silicone tubing (Silastic, Dow-Corning, Midland, MI).

Hemocompatibility. In their in vivo and in vitro studies on bilirubin detoxification, Lavin et al. (7) reported no statistically significant changes in most blood components except a $20 \%$ decrease in red blood cell count in both experiments and controls. The reactor was made of commercially available agarose beads used in chromatography. These beads have a diameter ranging from 60 to $140 \mu \mathrm{m}$. If the beads are assumed perfectly spherical, it can be calculated that the smallest opening between adjacent beads would permit the passage of about $10 \mu \mathrm{m}$ diameter spherical particles (16). This is approximately the diameter of red blood cells. Agarose beads of 180 to $250 \mu \mathrm{m}$ in diameter were selected in our study because they have a larger theoretical minimum space between beads that allows passage of about 30 $\mu \mathrm{m}$ diameter spheres (16). Using these larger diameter beads, red cell counts were monitored both in vitro and in vivo.

To simulate the potential in vivo use of the reactor, the in vitro studies were performed using a closed loop circuit. Freshly drawn adult human blood $(140 \mathrm{~mL})$ heparinized at $10 \mathrm{U} / \mathrm{mL}$ was placed in a reservoir and perfused through the reactor. The in vivo studies were performed according to Lavin et al. (7). All animal care was in accordance with the NIH guidelines and was approved by the Massachusetts Institute of Technology Committee on Animal Care. Briefly, homozygous male Gunn rats (Blue Spruce Farms, Altamont, NY) of $350 \mathrm{~g}$ body wt were used. After the rats were anesthetized using nembutol (Henry Schein Inc., Port Washington, NY; $4 \mathrm{mg}$ of anesthetic per $100 \mathrm{~g}$ of body wt), the left carotid artery and jugular vein were cannulated using PE-50 polyethylene tubing (Clay Adams, Parsippany, NJ), and $2000 \mathrm{U}$ of heparin were injected. The blood, pumped at $0.7 \mathrm{~mL} /$ min from the artery, was passed through the reactor containing $3 \mathrm{~mL}$ of beads and returned to the rat via the jugular vein. The apparatus was initially primed with about $4 \mathrm{~mL}$ of $0.9 \%$ saline solution containing $1000 \mathrm{U}$ of heparin. All the rats regained full consciousness before the experiment began. Blood samples of $0.7 \mathrm{~mL}$ each were collected from the arterial shunt at the beginning and at the end of the 90 -min study. All blood samples were drawn in vacutainer tubes containing EDTA (Becton Dickinson, Rockville, MD).

Complete blood cell counts were measured by Bioran Medical Laboratory (Cambridge, MA) using a coulter counter (Coulter Electronics, Hialeah, FL), and the cell counts were normalized by the count at the start of the experiment. Serum albumin and plasma bilirubin concentrations in Gunn rats were determined by the method of Doumas et al. (9) and the method of Jendrassik and Grof (10), respectively. Typically the serum albumin and bilirubin concentrations were $500 \mu \mathrm{mol} / \mathrm{L}$ and $6 \mathrm{mg} / \mathrm{dL}$, respectively.

Simulation of bilirubin detoxification. Most bilirubin circulates in the blood bound to serum albumin $(17,18)$. Stoichiometric bilirubin-serum albumin binding analysis and experimental measurements of unbound bilirubin showed that the unbound bilirubin concentration in plasma is small ( 3 to $30 \mathrm{nM}$ ) and is well approximated by the following expression $(15,19)$

$$
\mathrm{b}=\mathrm{s} / \mathrm{K}_{1}(1.1-\mathrm{s})
$$

where $b$ is the unbound bilirubin concentration, $s$ is the molar ratio of the total bilirubin concentration divided by the serum albumin concentration, and $\mathrm{K}_{1}$ is the bilirubin serum albumin stoichiometric equilibrium constant $\left(\mathrm{K}_{1}=60 \mu \mathrm{M}^{-1}\right)$.

The mechanism of bilirubin toxicity in vivo, whereas poorly understood, probably stems from its low aqueous solubility [5 $\mathrm{nM}$ at $\mathrm{pH} 7.4(17,18)]$ which may lead to the transport and accumulation of unbound bilirubin in several tissues where it interferes with cell functions (19). From the plasma disappearance curve of intravenous injections of radiolabeled bilirubin in adults, a three-compartment model of bilirubin distribution within the body (Fig. 1) has been considered to be the most physiologically reasonable representation $(20,21)$. The three compartments are considered to represent plasma, hepatic, and extrahepatic-extravascular pools of unconjugated bilirubin. However, the presence of unconjugated bilirubin in meconium stools from both premature and term infants $(19,22)$ suggests that unconjugated bilirubin is present in the gut during neonatal jaundice. A fourth compartment was then added to represent the intestinal pool of unconjugated bilirubin (Fig. 1). Bilirubin production results mainly from the catabolism of $\mathrm{Hb}$ in the cells of the reticuloendothelial system which include macrophages and phagocytic endothelial cells lining blood sinuses in various organs (23). However, the bilirubin production rate for each organ is not known. Therefore, an overall bilirubin production function is commonly used $(20,21)$ and represented as a single 


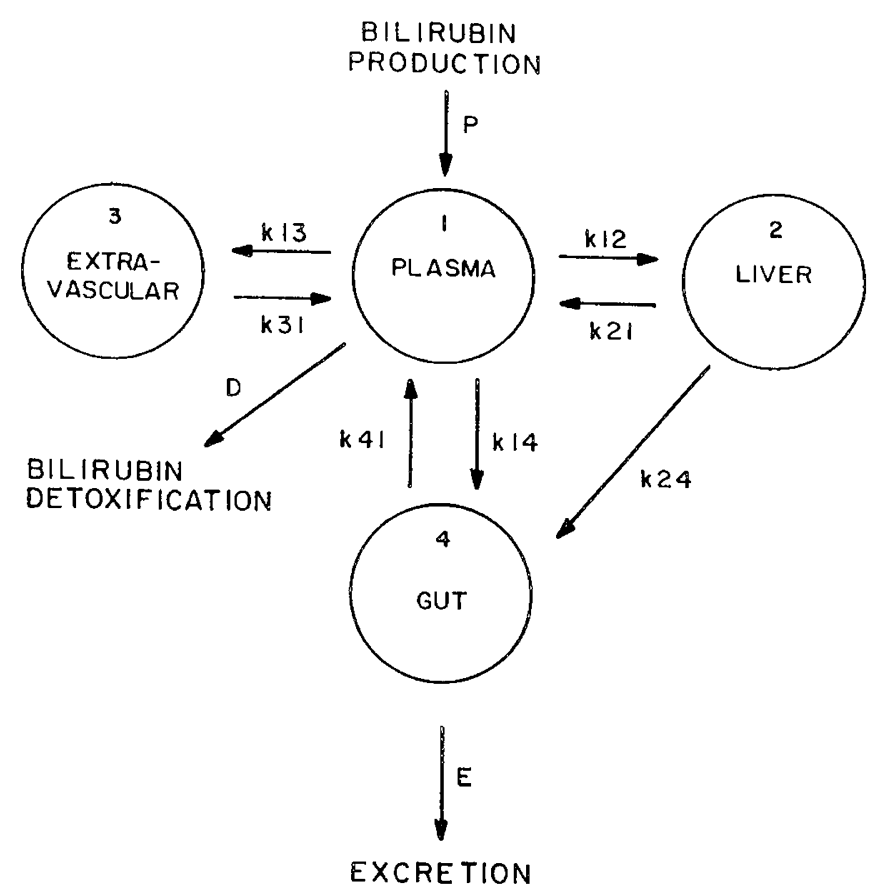

Fig. 1. Compartment model of bilirubin distribution within the body; plasma (1), hepatic (2), extrahepatic-extravascular (3), and intestinal (4) pools of unconjugated bilirubin.

input into the plasma pool (Fig. 1). Bilirubin released into the plasma by the reticuloendothelial cells circulates bound to serum albumin and is eliminated from the bloodstream by the hepatocytes which are represented in Figure 1 by the hepatic pool. Excretion of conjugated bilirubin by the hepatocytes is represented by the transport of bilirubin from the hepatic to the intestinal pool. In the gut, bacterial flora deconjugate and reduce the pigment to various compounds which are excreted in feces and urine. The formation of these compounds from unconjugated bilirubin is represented as a single arrow leaving the intestinal pool. The potential reabsorption of unconjugated bilirubin during its enterohepatic circulation is represented by a set of arrows between both intestinal and plasma pools. The several other arrows represent bilirubin transport between the different pools.

According to the kinetic study of Berk (21), bilirubin transport from one compartment to another may be represented by first order kinetics and the rate of change of bilirubin in a given pool by an ordinary differential equation. Thus, the bilirubin metabolism and the extracorporeal bilirubin detoxification (Fig. 1) may be modeled by a set of differential equations, as follows:

$$
\begin{gathered}
\mathrm{dC}_{1} / \mathrm{dt}=-\left(\mathrm{k}_{12}+\mathrm{k}_{13}+\mathrm{k}_{14}\right) \mathrm{C}_{1}+\mathrm{k}_{21} \mathrm{C}_{2} \\
+\mathrm{k}_{31} \mathrm{C}_{3}+\mathrm{k}_{41} \mathrm{C}_{4}+\mathrm{wP} / \mathrm{V}_{1}-\mathrm{D} / \mathrm{V}_{1} \\
\mathrm{dC}_{2} / \mathrm{dt}=-\left(\mathrm{k}_{21}+\mathrm{k}_{24}\right) \mathrm{C}_{2}+\mathrm{k}_{12} \mathrm{C}_{1} \\
\mathrm{dC}_{3} / \mathrm{dt}=-\mathrm{k}_{31} \mathrm{C}_{3}+\mathrm{k}_{13} \mathrm{C}_{1} \\
\mathrm{dC}_{4} / \mathrm{dt}=-\mathrm{k}_{41} \mathrm{C}_{4}+\mathrm{k}_{24} \mathrm{C}_{2}+\mathrm{k}_{14} \mathrm{C}_{1}-\mathrm{wE} / \mathrm{V}_{4}
\end{gathered}
$$

with $\mathrm{P}$, bilirubin production function; $\mathrm{D}$, reactor detoxification function; $\mathrm{C}_{\mathrm{i}}$, bilirubin concentration in pool $\mathrm{i}$ (Fig. 1); w, body wt; $V_{1}$, volume of the plasma pool; $V_{4}$, volume of the intestinal pool; $\mathrm{E}$, excretion function; $\mathrm{k}_{\mathrm{ij}}$, rate constants.

The intercompartmental rate constants $\mathrm{k}_{21}, \mathrm{k}_{13}$ and $\mathrm{k}_{31}, \mathrm{k}_{41}$ were taken as reported by Berk and coworkers $(20,21)$. The bilirubin production $(P)$, hepatic uptake $\left(\mathrm{k}_{12}\right)$, and conjugation $\left(\mathrm{k}_{24}\right)$ rates were modeled according to Gartner et al. (24) and the bilirubin excretion rate from the intestinal pool according to Odell and coworkers $(19,22)$. These studies showed that during the first days after birth the rates of bilirubin production, hepatic uptake, hepatic conjugation, and excretion vary exponentially with time. Accordingly, the several rates and rate constants were modeled as follows:

Bilirubin production

$$
P=P_{n} \times P_{\text {birth }} \times e^{-k_{1} t} \text { for } t \leq t_{p}
$$

with

$$
\mathrm{k}_{1}=\left[\ln \mathrm{P}_{\text {birth }}\right] / \mathrm{t}_{\mathrm{p}}
$$

and

$$
\mathrm{P}=\mathrm{P}_{\mathrm{n}} \text { for } \mathrm{t}>\mathrm{t}_{\mathrm{p}}
$$

where $P_{n}$ is the normal adult bilirubin production and $P_{\text {birth }}$ is a constant by which the normal adult bilirubin production was multiplied to conform with the production at birth. The parameter $t_{p}$ is the time at which the rate $P$ becomes the normal adult value.

Hepatic uptake

$$
\mathrm{k}_{12}=\left(\mathrm{k}_{12}\right)_{\mathrm{n}}\left(1-\mathrm{e}^{-\mathrm{k}_{2} \mathrm{t}}\right)
$$

where $\left(\mathrm{k}_{12}\right)_{\mathrm{n}}$ is the normal adult bilirubin hepatic uptake rate constant.

Hepatic conjugation

$$
\mathrm{k}_{24}=\left(\mathrm{k}_{24}\right)_{\mathrm{n}}\left(1-\mathrm{e}^{\mathrm{k}_{4} \mathrm{t}}\right)
$$

where $\left(\mathrm{k}_{24}\right)_{\mathrm{n}}$ is the normal adult bilirubin conjugation rate constant.

\section{Bilirubin excretion}

$$
\mathrm{E}=\mathrm{E}_{\mathrm{n}}\left(1-\mathrm{e}^{-\mathrm{kt}}\right)
$$

where $E_{n}$ is the bilirubin execretion rate in infants of $6 \mathrm{~d}$ of age and older $(19,22)$.

The extracorporeal rate of bilirubin detoxification from the plasma pool or bilirubin detoxification function (D) may be represented by the bilirubin concentration change over the reactor multiplied by the flow rate.

$$
\mathrm{D}=\mathrm{Q}\left(\mathrm{C}_{\text {in }}-\mathrm{C}_{\text {out }}\right)
$$

The in vitro performance of a packed bed reactor containing immobilized bilirubin oxidase has been studied by Mullon $e t$ al. (15). The bilirubin concentration change over the reactor was represented as follows:

$$
\mathrm{C}_{\text {out }}-\mathrm{C}_{\text {in }}=-\left(\mathrm{kE} \mathrm{b}_{\mathrm{i}} \mathrm{V}\right) / \mathrm{Q}
$$

where $\mathrm{C}_{\text {out }}$, bilirubin concentration at the reactor outlet; $\mathrm{C}_{\mathrm{in}}$, bilirubin concentration at the reactor inlet; $\mathrm{Q}$, flow rate; $\mathrm{V}$, volume of beads; $\mathrm{E}$, immobilized enzyme per volume of beads; $b_{i}$, unbound bilirubin concentration at the reactor inlet; $k$, constant of proportionality.

Equation 13 combined with equation 12 yields the bilirubin detoxification function:

$$
\mathrm{D}=\mathrm{R} \mathrm{V}=\left(\mathrm{kE} \mathrm{b}_{\mathrm{i}}\right) \mathrm{V}
$$

The unbound unconjugated bilirubin concentration at the reactor inlet $\left(b_{i}\right)$ is defined by the plasma bilirubin and albumin concentrations (equation 1), and by the presence of displacing substances competing at the bilirubin-serum albumin binding sites. Bilirubin oxidase catalyzes the oxidation of bilirubin to biliverdin which is a more soluble tetrapyrrole $(1,17)$. Biliverdin is then further oxidized to a purple pigment (25). The second oxidation step may yield products more soluble and more rapidly cleared from the plasma than biliverdin. However, both reaction products are bilirubin displacing substances $(15,26)$, and therefore, the unbound bilirubin concentration at the reactor inlet depends on the clearance rate of the products of the reaction from the plasma pool.

The metabolism and the clearance rate of the reaction products 
from the plasma pool are unknown. To simulate the in vivo performance of the extracorporeal detoxification, two product clearance conditions were considered: 1 ) rapid clearance of both products; 2) slow clearance of both reaction products. The true in vivo product clearance should be within these conditions.

Rapid clearance of reaction products. The unbound bilirubin concentration at the reactor inlet is not affected by the presence of the reaction products. The inlet unbound concentration $\left(b_{i}\right)$ is given by equation 1 and the detoxification function becomes:

$$
\mathrm{D}=\left(\mathrm{kEV} / \mathrm{K}_{1}\right)\left(\mathrm{C}_{1} / 1.1 \mathrm{~A}-\mathrm{C}_{1}\right)
$$

where $\mathrm{A}$ is the serum albumin concentration.

Slow product clearance. The products of the reaction stay in the plasma pool during the treatment. According to the study by Mullon et al. (15) the in vitro unbound bilirubin concentration in the presence of the products of the reaction is well approximated by the following equation:

$$
\mathrm{b}=\mathrm{C}_{1 \mathrm{o}} /\left[\mathrm{K}_{1}\left(1.1 \mathrm{~A}-\mathrm{C}_{1 \mathrm{o}}\right)\right]
$$

where $C_{10}$ is the plasma bilirubin concentration at the onset of the treatment. Combining equations 15 and 16 leads to,

$$
\mathrm{D}=\mathrm{kEVb}=\text { constant }
$$

Using the fourth order Runge-Kutta algorithm (27), equations 2 to 17 were solved numerically on a VAX 11/750 computer running DEC VMS operating system (Digital Equipment Corporation, Maynard, MA).

\section{RESULTS AND DISCUSSION}

Simulation of in vivo bilirubin detoxification. Hyperbilirubinemia in the neonate was simulated with the following production rate, excretion rate, and intercompartmental rate constants: $\mathrm{k}_{21}=0.4 \mathrm{~h}^{-1}, \mathrm{k}_{13}=0.28 \mathrm{~h}^{-1}, \mathrm{k}_{31}=0.1 \mathrm{~h}^{-1}, \mathrm{k}_{14}=0.005 \mathrm{~h}^{-1}, \mathrm{k}_{41}$ $=0.4 \mathrm{~h}^{-1},\left(\mathrm{k}_{12}\right)_{\mathrm{n}}=1.0 \mathrm{~h}^{-1},\left(\mathrm{k}_{24}\right)_{\mathrm{n}}=0.67 \mathrm{~h}^{-1}, \mathrm{P}_{\text {birth }}=2.0, \mathrm{P}_{\mathrm{n}}=$ $3.8 \mathrm{mg} / \mathrm{kg} / \mathrm{d}, \mathrm{E}_{\mathrm{n}}=5 \mathrm{mg} / \mathrm{kg} / \mathrm{d}, \mathrm{V}_{1}=40 \mathrm{~mL} / \mathrm{kg}$ of body $\mathrm{wt}, \mathrm{V}_{4}=$ $80 \mathrm{~mL} / \mathrm{kg}$ of body wt, and the initial concentrations $\mathrm{C}_{1}=\mathrm{C}_{2}=$ $\mathrm{C}_{3}=1.0 \mathrm{mg} / \mathrm{dL}$ and $\mathrm{C}_{4}=\mathrm{B}_{4} / \mathrm{V}_{4}$ where $\mathrm{B}_{4}$ is the initial amount of unconjugated bilirubin in the intestinal pool $\left(B_{4}=250 \mathrm{mg}\right.$ (19)). The intercompartmental rate constants were from Berk and coworkers $(20,21)$ and the bilirubin production factor $\left(\mathrm{P}_{\text {birth }}\right)$ from Valaes (28). The initial concentrations, the production rate and the excretion rate were from Odell and coworkers $(19,22)$.

The adjustable parameters $\mathrm{k}, \mathrm{k}_{2}, \mathrm{k}_{4}$, and $\mathrm{t}_{\mathrm{p}}$ were evaluated by comparison with the data reported by Gartner et al. (24) who studied bilirubin transport and metabolism in human newborn infants and in newborn rhesus monkeys. Figure 2 shows good agreement between the serum bilirubin concentrations reported

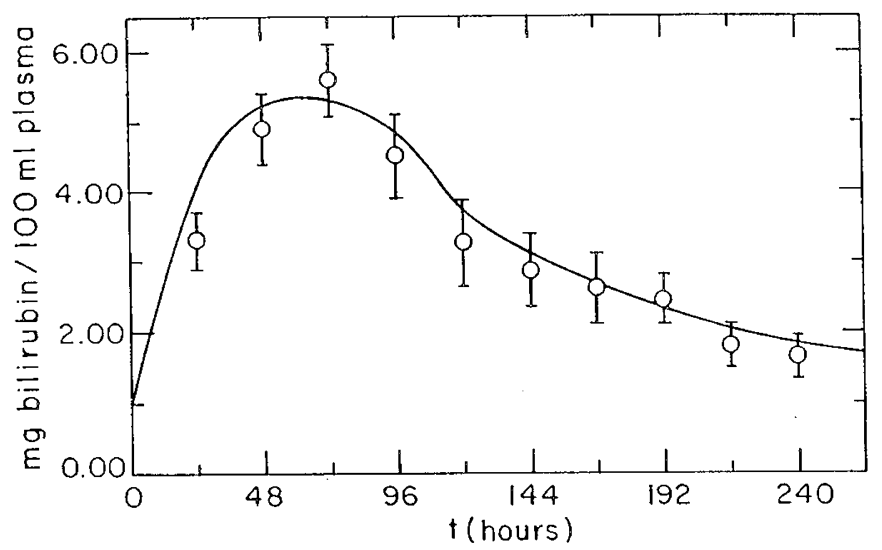

Fig. 2. Plasma bilirubin concentration as a function of time. The open circle and SEM represent the clinical data, of Gartner et al. (24) for human newborn infants $(n=29)$. The solid line represents plasma bilirubin concentrations predicted by the computer simulation. by Gartner et al. (24) for human newborn infants and the serum bilirubin concentrations predicted by the model $\left(\mathrm{k}=0.005 \mathrm{~h}^{-1}\right.$, $\mathrm{k}_{2}=-0.045 \mathrm{~h}^{-1}, \mathrm{k}_{4}=-0.0015 \mathrm{~h}^{-1}$, and $\mathrm{t}_{\mathrm{p}}=30 \mathrm{~d}$ ).

Simulation of a 4-h treatment in a hyperbilirubinemic newborn infant is presented in Figure 3 for both rapid and slow clearance of the products of the reaction. The bilirubin production rate was chosen to be four times the normal bilirubin production in newborns. This rate of production is within the bilirubin production range for hemolytic jaundice $(19,28)$. The treatment was simulated for a $2-\mathrm{kg}$ premature infant, a reactor containing $10 \mathrm{~mL}$ of agarose beads with a catalytic activity of 25 $\mathrm{nmol} / \mathrm{min} / \mathrm{mL}$ of bead, a blood flow rate of $3.0 \mathrm{~mL} / \mathrm{min}$ through the reactor and a serum albumin concentration of $3.5 \mathrm{~g} / \mathrm{dL}$ (19). The treatment was initiated as the plasma bilirubin concentration reached $17 \mathrm{mg} / \mathrm{dL}$, reflecting the bilirubin plasma concentration at which blood exchange transfusion has been suggested for a $2.0-\mathrm{kg}$ premature infant $(2,29)$. Figure 3 shows a significant decrease in plasma bilirubin concentration for both reaction product clearance conditions. The simulation of a 4-h treatment predicts a $32 \%$ decrease in plasma bilirubin concentration for rapid clearance of the reaction products and a $65 \%$ decrease for slow clearance of the reaction products. Higher reduction of plasma bilirubin with the slow clearance condition was expected because the products of the reaction compete for the bilirubin binding sites on the serum albumin molecules $(15,26)$ which leads to a higher unbound bilirubin concentration and a higher enzymatic rate of bilirubin degradation (equation 14). The true plasma clearance of the products of the reaction should be within the slow and fast clearance conditions and the reduction in plasma bilirubin concentration within the predicted percentages (32 to $65 \%$ ). Such an efficacy of the device and associated decrease in plasma bilirubin might alleviate the need for blood transfusion.

In vivo and in vitro red cell hemolysis. In their in vivo and in vitro studies on bilirubin detoxification, Lavin et al. (7) reported no statistically significant change in platelet or white cell count but a $20 \%$ decrease in red blood cell count using immobilized bilirubin oxidase and agarose beads only. The present in vivo and in vitro studies were aimed at reducing or eliminating red blood cell hemolysis for future use of the reactor in humans. Agarose beads of 180 to $250 \mu \mathrm{m}$ in diameter were selected because they have a higher theoretical minimum space between beads $(30 \mu \mathrm{m})$ than the 60 to $140 \mu \mathrm{m}$ beads used by Lavin et al. (7) (minimum space between beads $10 \mu \mathrm{m}$ ). Hemolysis may result from poor blood biocompatibility of the extracorporeal circuit associated with a direct mechanical effect on the red blood

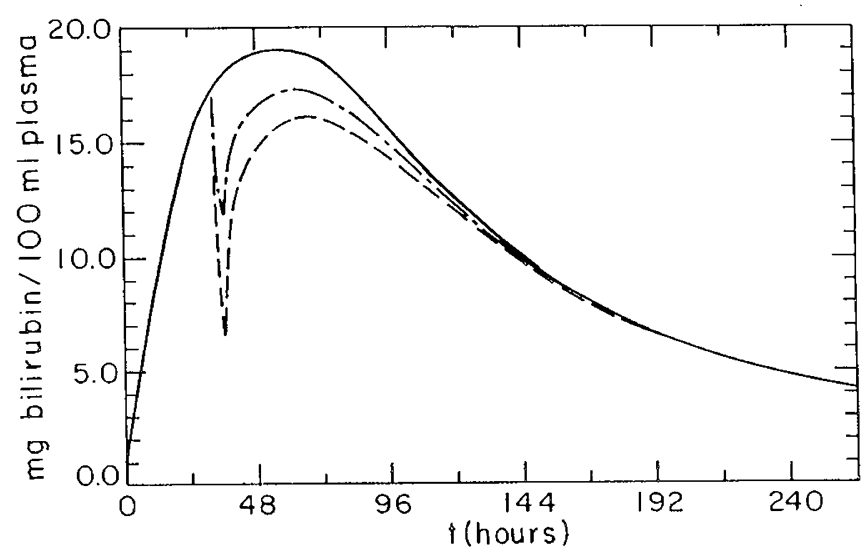

Fig. 3. Predicted plasma bilirubin concentration as a function of time in hyperbilirubinemic newborn infants. The bilirubin production was assumed eight times the normal adult bilirubin production. Predicted plasma bilirubin concentrations: (-) in the absence of extracorporeal treatment, $(-\cdot-)$ for a 4 -h treatment and fast clearance of the products, $(--)$ for a 4-h treatment and slow clearance of the products. 
cells through shear forces $(16,30)$. A higher theoretical space between beads lowers the mechanical effect through lower shear forces.

Tables 1 and 2 show the red blood cell recovery under in vitro and in vivo conditions. Four Gunn rats were treated for $90 \mathrm{~min}$ with a reactor containing $3.0 \mathrm{~mL}$ of agarose. The blood flow rate through the reactor was $0.7 \mathrm{~mL} / \mathrm{min}$ and two of the four Gunn rats were treated with immobilized bilirubin oxidase $(1.7 \mathrm{mg}$ enzyme $/ \mathrm{mL}$ agarose). Besides the four in vivo experiments, two in vitro experiments were conducted using a closed loop circuit. Freshly drawn human blood $(140 \mathrm{~mL})$ heparinized at $10 \mathrm{U} / \mathrm{mL}$ was pumped through $4.0 \mathrm{~mL}$ of agarose beads at a flow rate of $1.2 \mathrm{~mL} / \mathrm{min}$ for a period of $2 \mathrm{~h}$. In one of the two in vitro experiments, the blood was exposed to immobilized bilirubin oxidase (1.7 mg enzyme $/ \mathrm{mL}$ agarose beads). For both in vitro and in vivo conditions, with and without bilirubin oxidase, the red blood cell count did not drop during the course of the experiments. Although the plasma bilirubin concentration stayed unchanged in the two rats treated with agarose beads only (experiments $\mathrm{A}$ and $\mathrm{B}$ ), the plasma bilirubin concentration decreased by 15 and $20 \%$ in the two rats treated with a reactor containing bilirubin oxidase (experiments $\mathrm{C}$ and $\mathrm{D}$ ). The observed decreases in plasma bilirubin concentration are in agreement with the data reported by Lavin et al. (7) who observed a $50 \%$ decrease in plasma bilirubin concentration in Gunn rats using a $8-\mathrm{mL}$ reactor volume. Lavin et al. (7) used cyanogenbromide-activated agarose beads with the same amount of enzyme immobilized per volume of beads. However, the use of bilirubin oxidase immobilized onto tresyl-chloride-activated beads may be preferrable because tresyl-chloride chemistry has been shown to yield more stable protein-support bonds (12).

\section{CONCLUSION}

A simulation of bilirubin distribution in the body and subsequent removal by extracorporeal bilirubin oxidase treatment was developed to provide additional understanding of the detoxification and to predict the treatment efficacy in hyperbilirubinemic neonates. Using a $10-\mathrm{mL}$ reactor volume, the simulation predicts a lowering of 32 to $65 \%$ of the initial plasma bilirubin concentration $(17 \mathrm{mg} / \mathrm{dL})$ in a $2-\mathrm{kg}$ preterm infant during a 4 -h treatment. This drop in plasma bilirubin concentration might be

Table 1. In vivo red blood cell recovery: normalized red blood cell counts (final $R B C /$ initial $R B C$ )*

\begin{tabular}{cccc}
\hline Experiment & $\begin{array}{c}\text { Reactor vol } \\
\text { (mL of beads) }\end{array}$ & $\begin{array}{c}\text { Enzyme } \\
\text { (mg/mL beads) }\end{array}$ & $\begin{array}{c}\text { RBC } \\
\text { (final/initial) }\end{array}$ \\
\hline A & 3 & 0 & 1.07 \\
B & 3 & 0 & 1.20 \\
C & 3 & 1.7 & 1.01 \\
D & 3 & 1.7 & 1.06 \\
\hline
\end{tabular}

* Four Gunn rats with an initial plasma bilirubin concentration ranging from 5.5 to $6.5 \mathrm{mg} / \mathrm{dL}$ were treated for $90 \mathrm{~min}$. The blood flow rate in the extracorporeal reactor was $0.7 \mathrm{~mL} / \mathrm{min}$. Upon completion of the treatment, the plasma bilirubin concentration was unchanged in experiments $\mathrm{A}$ and $\mathrm{B}$. In experiments $\mathrm{C}$ and $\mathrm{D}, 15 \%$ and $20 \%$ decrease in plasma bilirubin concentration were observed, respectively.

Table 2. In vitro red blood cell recovery: normalized red blood cell counts (RBC/initial $R B C)^{*}$

\begin{tabular}{ccccc}
\hline & \multirow{2}{*}{$\begin{array}{c}\text { Reactor vol } \\
\text { Experiment }\end{array}$} & $\begin{array}{c}\text { Enzyme } \\
(\mathrm{mL} \text { of beads) }\end{array}$ & \multicolumn{2}{c}{$\mathrm{RBC}$ ratios } \\
\cline { 4 - 5 } & $\mathrm{mg} / \mathrm{mL}$ beads) & $\mathrm{t}=60 \mathrm{~min}$ & $\mathrm{t}=120 \mathrm{~min}$ \\
\hline $\mathrm{F}$ & 4 & 0 & 0.92 & 0.90 \\
& 4 & 1.7 & 1.00 & 0.98 \\
\hline
\end{tabular}

* Heparinized human blood $(140 \mathrm{~mL}, 10 \mathrm{U}$ heparin $/ \mathrm{mL})$ was recycled through the reactor at a flow rate of $1.2 \mathrm{~mL} / \mathrm{min}$. sufficient to alleviate the use of blood transfusion. Other investigators have reported the use of hemoperfusion over ion exchange and affinity chromatography resins for removal of bilirubin $(31,32)$ but due to the limited adsorption capacity of the resins, the recommended sizes of the columns ranged between 25 to $65 \%$ of the neonate's blood volume. The resins also retained other essential compounds such as cortisol and thyroxine (31, 32). Bilirubin oxidase catalyzes the oxidation of bilirubin to biliverdin and biliverdin to a purple pigment (25). Researchers studying the toxic effects of bilirubin and biliverdin on the metabolism of mammalian cells in vitro $(33,34)$ found that biliverdin is much less toxic than bilirubin. The purple pigment is still unknown and further work must be done to characterize its toxicity. However, it was shown that the products of the reaction (biliverdin, purple pigment) are noncytotoxic, nonmutagenic, and nonteratogenic (7). Although the bilirubin displacing property of the products of the reaction was considered in the enzymatic rate of bilirubin degradation (slow clearance and fast clearance conditions, equations 15 and 16), their accumulation in the blood stream may further affect the efficiency of the detoxification process. For instance, biliverdin (about $30 \%$ of the reaction products) may be reconverted to bilirubin by the cells of the reticuloendothelial system. The products may also interfere with the net movement of bilirubin from the tissues. The potential effect of the reaction products on the rate constants between bilirubin pools is not known and was not included in the model. However, the displacement of unconjugated bilirubin from several tissues would probably increase the unbound bilirubin concentration in the blood stream leading to a higher rate of bilirubin degradation by the bilirubin oxidase reactor (equation 14).

The simulation predicts the bilirubin concentration in the plasma as well as in the extravascular compartment where the toxic effect of bilirubin occurs. Unfortunately, data concerning bilirubin concentrations in the extravascular compartment are not available for comparison. Such data would provide additional information in estimating the adjustable parameters.

The absence of red blood cell lysis using agarose beads of 180 to $250 \mu \mathrm{m}$ in diameter instead of 60 to $140 \mu \mathrm{m}$ (7) represents a potentially safer use of the device. However, because neonatal red blood cells differ in their membrane properties from adult red blood cells, whether the degree of hemolysis would be similarly reduced still needs to be investigated. Additional studies should also be carried out with lower amounts of blood anticoagulant (heparin) to use this technique clinically.

In summary, this reactor may provide a new approach to the treatment of neonatal jaundice and serve as a model for the clinical application of immobilized enzymes for the detoxification of compounds in blood.

Acknowledgments. The authors thank J. Behm and P. Soltys for helpful discussions and assistance.

\section{REFERENCES}

1. McDonagh AF 1979 Bile pigments: Bilitrienes and 5,15-bilidienes. In: Dolphin D (ed) The Porphyrins, Vol VI. Academic Press, New York, pp 293-491

2. Maisels MJ 1981 Neonatal Jaundice. In: Avery GB (ed) Neonatology. Lippinicott, Philadelphia, pp 473-544

3. Maurer HM, Kirkpatrick BV, McWilliams NB, Draper DA, Bryla DA 1985 Phototherapy for hyperbilirubinemia of hemolytic disease of the newborn. Pediatrics 75(suppl):407-412

4. Odell GB, Gutcher GR, Whittington PF 1983 Enteral administration of agar as an effective adjunct to phototherapy of neonatal hyperbilirubinemia. Pediatr Res 17:810-814

5. Cohen AN, Ostrow JD 1980 New concepts in phototherapy: photoisomerization of bilirubin IX $\alpha$ and potential toxic effects of light. Pediatrics 65:740750

6. Speck WT, Rosenkranz HS 1975 The bilirubin induced photodegradation of deoxyribonucleic acid. Pediatr Res 9:703-705

7. Lavin A, Sung C, Klibanov AM, Langer R 1985 Enzymatic removal of bilirubin from blood: A potential treatment for neonatal jaundice. Science $230: 543-$ 545

8. Lowry OH, Rosebrough NJ, Farr AL, Randall RJJ 1951 Protein measurement with the folin phenol reagent. J Biol Chem 193:265-275 
9. Doumas B, Watson W, and Biggs H 1971 Albumin standards and the measurement of serum albumin with bromcresol green. Clin Chim Acta 31:8796

10. Jendrassik L, Grof P 1938 Vereinfachte photometrische methoden zur bestimmung des blut bilirubins. Biochem Z 297:81-89

11. Nilsson K, Mosbach K 1984 Immobilization of ligands with organic sulfonyl chlorides. In: Jakoby W (ed) Enzyme Purification and Related Techniques. Methods Enzymol 104:56-69

12. Comfort AR, Mullon CJP, Langer R 1988 The influence of bond chemistry on immobilized enzyme systems for ex vivo use. Biotech Bioeng 32:554563

13. Yang CV, Linhardt RJ, Bernstein H, Cooney CL, Langer R 1985 Purification and characterization of heparinase from flavobacterium heparinum. $J$ Biol Chem 260:1849-1857

14. Mullon CJP, Saltzman WM, Langer R 1988 Computer based visualization for quantitative and qualitative analysis of the distribution of matrix-bound proteins. Bio/Techn 6:927-929

15. Mullon CJP, Klibanov AM, Langer R 1988 Kinetics of bilirubin oxidase and modeling of an immobilized bilirubin oxidase reactor for bilirubin detoxification. Biotech Bioeng 31:536-546

16. Ostlund RE 1988 Immunosorbent chemistry: A study of agarose-based column sorbents for the removal of low-density lipoprotein (LDL) from blood. Artif Organs 11:366-374

17. Brodersen R 1982 Physical chemistry of bilirubin binding to macromolecules and membranes. In: Heirwegh G, Brown SB (eds) Bilirubin Chemistry, Vol I. CRC Press, Boca Raton, FL, pp 75-124

18. Brodersen R 1979 Binding of bilirubin to albumin. CRC Crit Rev Clin Lab Sci 11:305-399

19. Odell GB 1980 Monographs in Neonatology: Neonatal Hyperbilirubinemia Grune \& Stratton, New York, pp 51-120

20. Berk PD, Howe RB, Bloomer JR, Berlin NI 1969 Studies of bilirubin kinetics in normal adults. J Clin Invest 48:2176-2190

21. Berk DP 1977 A computer simulation study relating to the treatment of fulminant hepatic failure by hemoperfusion. Proc Soc Exp Biol Med 155:535-539
22. Poland RL, Odell GB 1971 Physiologic jaundice: the enterohapatic circulation of bilirubin. N Engl J Med 284:1-6

23. Robbins S, Cotran R, Vinay K 1984 Pathologic Basis of Disease, 3rd ed, WB Saunders Company, Philadelphia, pp 58-60

24. Gartner LM, Lee K, Vaisman S, Lane D, Zafaru I 1977 Development of bilirubin transport and metabolism in the newborn rhesus monkey. J Pediatr 90P:513-531

25. Tanaka N, Murao S 1985 Reaction of bilirubin oxidase produced by Myrothecium verrucaria MT-1. Agric Biol Chem 49:843-844

26. Ahlfors CE 1981 Competitive interaction of biliverdin and bilirubin only at the primary bilirubin binding site on human albumin. Anal Biochem 110:295-307

27. Carnahan B, Lurther HA, Wilkes JO 1981 Applied Numerical Methods. John Wiley and Sons, New York, pp 103-109

28. Valaes T. 1976 Bilirubin metabolism, review and discussion of inborn errors. Clin Perinatol 3:177-209

29. Koops B, Battaglia FC 1987 Jaundice in the newborn infant. In: Kemp CH Silver HK, O'Brien D, Fulginiti VA. Current Pediatric Diagnosis and Treatment, Vol 9. Appleton and Lange, Norwalk, CT, pp 75-80

30. van Oeveren W, Wildewuur CR 1987 Blood compatibility of cardiopulmonary by pass circuits. Perfusion 2:237-244

31. Scharschmidt BF, Plotz BH, Berk PD, Waggonerr JG, Vergalla J 1974 Remov ing substances from blood by affinity chromatography: removing bilirubin from the blood of jaundiced rats by hemoperfusion over albumin-conjugated agarose beads. J Clin Invest 53:786-791

32. Sideman S, Mor L, Brandes JM 1983 Bilirubin removal by hemoperfusion. In: Piskin E and Chang MS (eds) The Past, Present and Future of Artificial Organs. Meteksa Inc., Ankara, Turkey, pp 228-244

33. Cowger ML, Igo RP, Labbe RF 1965 The mechanism of bilirubin toxicity studied with purified enzyme and tissue culture systems. Biochem 4:27632770

34. Cowger ML 1974 Toxicity and protein binding of biliverdin and other bile pigment. In: Odell GB, Schaffer R and Simopoulos AP (eds). Phototherapy in the Newborn: An Overview. National Academy of Science, Washington DC, pp 93-113 